\title{
How electrolyte values affect COVID-19 patients at the time of application to the hospital?
}

\author{
Hastaneye başvuru sırasında elektrolit değerleri COVID-19 hastalarını nasıl \\ etkiler?
}

${ }^{1}$ M.D. Spec., Kartal Dr. LutfiKirdar Training and Research Hospital, Department of Internal Medicine,istanbul, Turkey

${ }^{2}$ M.D. Spec., Kartal Dr. LutfiKirdar Training and Research Hospital, Department of Internal Medicine,İstanbul, Turkey

Sorumlu Yazar: Kübra Aydın Bahat, M.D. Spec., Kartal Dr. LutfiKirdar Training and Research Hospital, Department of Internal Medicine,Istanbul, Turkey. E-mail:asbkubra@gmail.com Telefon: +90 5322707060

Başvuru Tarihi: 31.03.2021 Kabul Tarihi: 22.12 .2021 Yayınlanma Tarihi: 28.02.2022

Atff İçin:Kübra Aydın Bahat, Meral Meşe,How electrolyte values affect COVID-19 patients at the time of application to the hospital?,2022;6(1):1-6.

\section{ABSTRACT}

Aim: COVID-19 disease is life threatening. we aimed to evaluated the effect of electrolyte disturbances on the course of COVID-19 disease. Material and methods: Patients hospitalized with the diagnosis of COVID-19 were included in the study. Demographic characteristics, comorbidities, symptoms, clinical course, and laboratory parameters were recorded. Results: Totally 130 COVID-19 patients, 70 (54\%) of whom were female, were included in the study. The mean age was $56.6 \pm 16.4$ years. The most common symptom was cough $(57 \%)$ and the accompanying disease hypertension (45\%). $68 \%$ of the patients had hyponatremia and $29 \%$ had hypocalcemia. $95 \%$ of the patients were discharged. $5 \%$ died. There was a relationship between the need for oxygen and advanced age, male gender, presence of diabetes mellitus, cardiovascular disease, bilateral involvement in chest CT, lymphopenia, CRP, low calcium level, hypocalcemia, and secondary infection $(p=0.024$., $p=0.001, p=0.030, p=0.045, p=0.002, p=$ $0.010, p=0.000, p=0.022, p=0.048, p=0.001$, respectively). There was a relationship between the need for intensive care, male gender, low calcium level, hyponatremia conclusion the presence of secondary infection. (respectively, $p=0.045, p=0.023, p=0.011, p=0.001$ ). There was a correlation between the duration of hospitalization and low calcium level and low sodium level $(p=0.026, p=0.022)$. Conclusion: The severity of COVID-19 appears to be associated with low serum sodium and calcium concentrations, and regular electrolyte monitoring can be useful in follow-up.

Keywords: COVID-19; electrolyte; oxygen support

\section{öz}

Amaç: COVID-19 hastalığı, yaşamı tehdit etmektedir. Şiddetli hastalık seyrini ön görmek, hastalık takibinde önemlidir. Çalışmamızda elektrolit bozukluklarının COVID-19 nedeniyle hastaneye yatırılan hastaların klinik seyrine etkisini değerlendirmeyi amaçladık. Materyal ve metod: COVID-19 tanısı alan ve 11.03.2020-30.05.2020 tarihleri arasında yatarak tedavi gören hastalar çalışmaya alındı. Demografik özellikler, komorbiditeler, semptomlar, klinik seyir, laboratuvar parametreleri ve tedaviler kaydedildi. Sonuç: Çalışmaya 70'i (\% 54) kadın 130 COVID-19 hastası dahil edildi. Ortalama yaş $56.6 \pm 16.4$ yıldı. En sık görülen semptom öksürüktü (\% 57). En sık eşlik eden hastalık hipertansiyondu (\% 45). Hastaların\% 68'inde hiponatremi ve\% 29'unda hipokalsemi vardı. Hastaların\% 95'i tam iyileşme ile taburcu edildi, \% 5'i öldü.Oksijen ihtiyacı ile ileri yaş, erkek cinsiyet, diabetes mellitus varlığı, kardiyovasküler hastalık, göğüs tomografisinde bilateral tutulum, lenfopeni, CRP, düşük kalsiyum seviyesi, hipokalsemi ve sekonder enfeksiyon arasında anlamlı bir ilişki vardı (sırasyla $p=0.024, p=0,001, p=0,030, p=$ $0,045, p=0,002, p=0,010, p=0,000, p=0,022, p=0,048, p=0,001)$. Yoğun bakım ihtiyacı, erkek cinsiyet, düşük kalsiyum seviyesi, hiponatremi ve ikincil enfeksiyon varlığı arasında anlamlı bir ilişki vardı. (sırasıyla, $p=0,045, p=0,023, p=0,011 p=0,001$ ). Hastanede kalış süresi ile düşük kalsiyum seviyesi ve düşük sodyum seviyesi arasında anlamlı ilişki vardı $(p=0,026, p=0,022)$. Tartışma: COVID-19'un şiddeti, düşük serum sodyum ve kalsiyum konsantrasyonları ile ilişkili görünmektedir, COVID-19 hastalarının takibinde düzenli elektrolit takibi faydalı olabilir.

Anahtar kelimler: COVID 19, Elektrolit, oksijen desteği 


\section{INTRODUCTION}

The new type of coronavirus, which emerged at the end of 2019 and spread all over the world, has become a pandemic. The rapid spread of the virus infection that causes COVID-19, causing severe cases of pneumonia, incurability and fatal course make the impact of the virus important. Common symptoms of COVID-19 are fever, cough, and shortness of breath. It may cause various infection findings from asymptomatic to severe pneumonia (1). It has been shown that more than $75 \%$ of patients have kidney involvement during the course of COVID-19 disease (2). The most common forms of kidney involvement in COVID-19 are acute kidney damage, proteinuria, hematuria, and electrolyte imbalances $(2,3)$. In several studies, lower sodium ( $\mathrm{Na}$ ), potassium (K), and calcium ( $\mathrm{Ca}$ ) concentrations have been found to be associated with severe disease (3). however, data are limited. Therefore, we aimed to evaluate the effect of $\mathrm{Na}, \mathrm{K}$, and $\mathrm{Ca}$ serum concentrations on the course of COVID-19.

\section{MATERIALS AND METHODS}

Patients diagnosed with COVID-19 in our hospital between 11.03.2020 and 30.05.2020 were included in the study. Real-time reverse transcriptase-polymerase chain reaction test (rRT-PCR) for SARS-CoV-2 was applied to all patients presenting with findings suggestive of COVID-19 disease with nasopharyngeal and oropharyngeal samples. All patients with symptoms suggestive of COVID-19 were evaluated by chest computed tomography. The presence of ground glass opacities and areas of consolidation were determined as findings consistent with COVID-19 disease. Patients with positive rRT-PCR test for SARS-CoV-2 and / or typical lung tomography findings for COVID-19 disease were included in the study.

Demographic characteristics (gender, age), chronic diseases (hypertension (HT), diabetes mellitus (DM), chronic kidney disease (CKD), asthma, chronic obstructive pulmonary disease (COPD), congestive heart failure (CHF)), coronary vascular diseases (CVD such as myocardial infarction, angina pectoris and documented coronary heart disease, hospitalization symptoms (cough, fever, shortness of breath, diarrhea, vomiting, nausea, abdominal pain, myalgia, conjunctivitis, loss of smell / taste), need for oxygen supply (in room air) oxygen saturation $<93 \%$ ), history of secondary infection, need for intensive care, laboratory data (WBC, neutrophil, lymphocyte, platelet, CRP (C-reactive protein), albumin, $\mathrm{Na}, \mathrm{K}, \mathrm{Ca}$, chest tomography, treatments, clinical outcome (death, recovery), duration of hospitalization was evaluated.

Leukocytosis, neutrophilia, lymphopenia, increased CRP, defined according to the normal ranges given in the hospital laboratory as: white blood> $10800 \mathrm{u} / \mathrm{L}$ cells, leukocytosis; neutrophil count $>7700 \mathrm{u}$ / L, neutrophilia; lymphocyte count $1300 \mathrm{u} / \mathrm{L}$, lymphopenia; platelet count $<130000 \mathrm{u} / \mathrm{L}$, thrombocytopenia and CRP> $3 \mathrm{mg} / \mathrm{L}$ increased CRP value. The normal range of albumin was $3.5 \mathrm{~g} / \mathrm{dl}-5.2 \mathrm{~g} / \mathrm{dl}$, the normal range for $\mathrm{Na}$ was $136 \mathrm{mmol} / \mathrm{L}-146 \mathrm{mmol} / \mathrm{L}$, the normal range for $\mathrm{K}$ was $3.5 \mathrm{mmol} / \mathrm{L}-5.1 \mathrm{mmol} / \mathrm{L}$, the normal range for Ca was $8.4 \mathrm{mg} / \mathrm{dl}-10.6 \mathrm{mg} / \mathrm{dl}$ Treatments as recommended in the COVID-19 treatment protocol of the Ministry of Health (4).

\section{Statistical Analysis}

Data were analyzed using the SPSS 21.0 statistical program (IBM corp. Released 2012.IBM SPSS statistics for windows, Version 21.0. Amonk, NY: IBM Corb). A p-value of less than 0.05 was accepted as the statistical significance limit. Numerical variables were given as mean \pm standard deviation for normally distributed variables and as medians for skewed continuous variables. Categorical variables are shown as frequency. A Chi-square test was used to evaluate categorical data. In the analysis of continuous variables, independent sample T-test and Mann Whitney $U$ were used appropriately considering the distribution of the data. Kartal Dr. Lütfi Kırdar City Hospital Clinical Research Ethics Committee approved. (Decision number: 2020/514/180/4)

\section{RESULTS}

We included 130 COVID 19 patients, 70 (54\%) were female and 60 (46\%) were male. The mean age was $56.6 \pm 16.4$ (median: 57.5$)$ years. 82 patients $(63 \%)$ had positive rRT-PCR. All the patients had computerized tomography findings consistent with COVID-19 disease. $79 \%$ of patients had bilateral lesions, $22 \%$ had multiple unilateral lesions and $13 \%$ had unilateral one lesion compatible with COVID-19 disease. The most common symptoms were cough (in 76 patients,59\%), and fever (in 60 patients, 46\%). The most common comorbidities were HT (in 58 patients, 45\%) and DM (in 53 patients, $41 \%$ ).

White blood cell values were high in $14 \%$ (18 patients), the mean white blood cell value was $7220 \mathrm{u} / \mathrm{L}$. $48 \%$ (63 patients) were lymphopenic, the mean lymphocyte value was $1346 \mathrm{u} / \mathrm{L}$. The neutrophil values were high in $17 \%$ (22 patients), the mean neutrophil value was $4810 \mathrm{u} / \mathrm{L}$. Platelet values were low in $9 \%$ (in 12 patients), the mean platelet value was 204.884 $\mathrm{u} / \mathrm{L}$. CRP values were high in $85 \%$ (in 110 patients), and the average CRP value was $36.1 \mathrm{mg} / \mathrm{L}$. Na value was low in $32 \%$ of patients ( 41 patients), $K$ value was low in $4 \%$ of patients ( 5 patients), and Ca value was low in $26 \%$ of patients ( 34 patients). There was no patient with high $\mathrm{Na}$ level. $\mathrm{K}$ value was high in $4 \%$ of patients ( 5 patients) and Ca value were high in $1 \%$ of patients (1 patient).

Oxygen support was required in $38 \%$ of the patients (49 patients) during follow-up. The mean age and male gender were significantly higher in patients who needed oxygen than those who did not need oxygen. (60.6 years, $65 \%$ vs 52.2 years, $35 \%$, respectively, $p=0.001, p=0.019)$. DM and CVD were frequently accompanying patients in need of oxygen $(57 \%, 24 \%$ versus $31 \%, 11 \% ; p=0.003, p=0.045)$. In addition, the presence of bilateral lesions in chest tomography was significantly higher in patients who needed oxygen ( $94 \%$ versus $70 \% ; p=0.009$ ). Among the laboratory parameters studied, the mean lymphocyte count and $\mathrm{Ca}$ values of the patients who needed oxygen were significantly lower than the patients who did not need oxygen ( $1110 \mathrm{u} / \mathrm{L}, 8.6 \mathrm{mg} / \mathrm{L}$ versus $1490 \mathrm{u} / \mathrm{L}, 8.8 \mathrm{mg} / \mathrm{L}$, respectively; $\mathrm{p}=0.004, p=0.022$ ). The CRP value was 
found approximately 2 times higher in patients who needed oxygen than in patients who did not need oxygen $(53.7 \mathrm{mg} / \mathrm{L}$ versus $25.6 \mathrm{mg} / \mathrm{L}$, respectively; $\mathrm{p}=0.002$ ). Hypocalcemia was significantly higher in patients who did not require oxygen $(63 \%$ versus $10 \% \mathrm{p}=0.048)$. Secondary infections were more common in patients who needed oxygen than those who did not ( $27 \%$ vs $0.1 \% ; p=0.00) 11 \%$ of the patients (14 patients) needed intensive care during follow-up. Male gender was more common in patients who needed intensive care than patients who did not need intensive care $(71 \%$ versus $43 \%$; $p$ $=0.045)$. Ca values were significantly lower in patients who did not need intensive care $(8.4 \mathrm{mg} / \mathrm{L}$ versus $8.7 \mathrm{mg} / \mathrm{L} ; \mathrm{p}=$ 0.023 , respectively). Hyponatremia and secondary infections were more common in patients who needed intensive care than patients without intensive care $(27 \%, \% 42$ vs $64 \%, 7 \% ; p=0.011, p=0.001$, respectively)

The duration of hospitalization was associated with low calcium level and low sodium level. $(p=0.026, p=0.022$. Looking at the results, 123 patients (95\%) were discharged with full recovery. Seven patients died of acute respiratory distress syndrome (ARDS) development and shock. There was no significant relationship between white blood cell, neutrophil, thrombocyte, and potassium values in terms of oxygen demand or need for intensive care. The demographic characteristics and basic clinical characteristics of the study population regarding oxygen demand are detailed in table 1.

\section{DISCUSSION}

Since COVID-19 is a new disease that affects the whole world, data on the course of the disease are needed to help and guide clinicians. Electrolyte disturbances are a parameter that affects the course and follow-up of infectious diseases. Therefore, although the number of patients in this study is limited, it is one of the studies with a relatively high number of patients and may contribute to the limited evidence in this area $(1,3,5,6)$.

The mean age in our study was $56.6 \pm 16.4$ years. Average age comparable to other COVID-19 studies (51-70 years) $(7,8,9)$. More than half $(70 \%)$ of the patients in our study were women. The gender distribution varies according to the study $(10,13)$. In addition, as in many studies, age and male gender were found to be associated with the need for intensive care and oxygen need $(7,13-15)$.

In the first weeks of the outbreak, PCR tests were concluded within 48-72 hours due to the limited diagnostic capacity of laboratory tests. Therefore, all patients with suspected COVID 19 symptoms in our center received a CT scan to make a faster diagnosis. Most of our patients had findings consistent with COVID-19 in their radiographic images. Consistent with the literature, the findings are bilateral and the presence of consolidation has been associated with the need for intensive care $(6,16,18)$.

The most common symptoms of COVID-19 in our study were fever and cough. This is similar to other studies $(10,11)$. In our study, the most common accompanying diseases in the patient group were HT and DM, and in accordance with the literature, oxygen demand was significantly higher in patients with DM and CVD $(7,9,19)$.

We analyzed the factors associated with the need for oxygen support and intensive care. Lymphopenia hyponatremia and high CRP were the most common abnormal laboratory parameters in our patients. In general population studies, severe COVID-19 disease and the need for intensive care have been associated with leukocytosis, lymphopenia, neutrophil elevation, trombocytopenia and increased CRP $(9,11,12,14,19)$. In our study, a statistically significant relationship was found between lymphopenia and CRP between the need for intensive care and oxygen supply and the factors mentioned above. Lack of statistical significance with other laboratory parameters is probably the result of a small number of patients, which limits statistical analysis results.

In a meta-analysis, sodium and potassium levels were significantly lower in severe COVID-19 (3). Another study found that sodium, potassium, and chloride levels have high predictive power for COVID-19 to progress to severe disease (20). In a different study, lower basal sodium, chloride and higher mortality were associated with higher ICU and MV requirements and longer duration of hospitalization, and hyponatremia was frequent electrolyte disturbances $(6,21)$. The most common electrolyte disorder in our study was hyponatremia and was related to the need for intensive care.

In one study, it has been shown that sodium levels are inversely related to cytokine storm and IL-6 levels. It can be thought that low sodium levels will be an indirect sign of increased IL-6 levels and may be associated with the severe disease phenotype (22). Studies have found that low calcium levels are associated with poor prognosis and longer duration of hospitalization in COVID-19 disease (6). In our study, too, hypocalcemia was associated with oxygen demand and long duration of hospitalization. Calcium deficiency may be due to insufficient intake or insufficient absorption as a result of nausea and diarrhea that develops due to gastrointestinal system involvement of COVID-19.

In addition, tissue and organ hypoxia caused by the disease during the course of COVID-19 may contribute to hypocalcemia by causing cell membrane damage and calcium entry into the cell (23). In addition, renal hypoxia, endothelitis, proximal tubule damage and angiotensin converting enzyme 2 up regulation in kidney tissue caused by coagulation disorders associated with COVID-19 may cause electrolyte abnormalities $(24,25)$. In addition, inappropriate anti-diuretic hormone syndrome that may accompany viral pneumonias also contributes to electrolyte abnormalities (26).

Our study has some limitations. The low number of patients studied should be stated as a limitation. However, despite the small number of patients, clinicians interested in managing this patient group should be informed. In addition, diagnostic tests could not be performed to rule out other possible atypical pneumonia pathogens due to the high patient 
Table 1. The features of the patients stratified by the oxygen support in the follow-up.

\begin{tabular}{|c|c|c|c|c|}
\hline Parameters & Oxygen support (-) & Oxygen support (+) & Total & $p$ value \\
\hline & $\mathrm{n}: 81$ & $\mathrm{n}: 49$ & $\mathrm{n}: 130$ & \\
\hline $\begin{array}{l}\text { Demographic features } \\
\text { Age } \\
\text { Sex } \\
\text { Female, } \mathrm{n}(\%) \\
\text { Male, } \mathrm{n}(\%) \\
\text { DM, } \mathrm{n}(\%) \\
\text { Hypertension, } \mathrm{n}(\%) \\
\text { CHF, } \mathrm{n}(\%) \\
\text { CVD, } \mathrm{n}(\%) \\
\text { CKD, } \mathrm{n}(\%) \\
\text { Astma, } \mathrm{n}(\%) \\
\text { COLD, } \mathrm{n}(\%)\end{array}$ & $\begin{array}{l}52.2 \pm 16.3(54) \\
53(65) \\
28(35) \\
25(31) \\
32(40) \\
4(5) \\
9(11) \\
8(10) \\
7(9) \\
2(3)\end{array}$ & $\begin{array}{c}60.6 \pm 16.3(64) \\
17(35) \\
32(65) \\
28(57) \\
26(53) \\
3(6) \\
12(24) \\
9(18) \\
4(8) \\
2(4)\end{array}$ & $\begin{array}{c}56.6 \pm 16.4(56) \\
70(54) \\
60(46) \\
53(41) \\
58(45) \\
7(5) \\
21(16) \\
17(13) \\
11(9) \\
4(3)\end{array}$ & $\begin{array}{l}0.024 \\
0.001 \\
\\
0.003 \\
0.148 \\
1.000 \\
0.045 \\
0.186 \\
1.000 \\
0.632\end{array}$ \\
\hline $\begin{array}{l}\text { Clinical characteristics } \\
\text { Dispne, n (\%) } \\
\text { Fever, n (\%) } \\
\text { Cough, n (\%) } \\
\text { Nausea, n (\%) } \\
\text { Vomiting, n (\%) } \\
\text { Diarrhoea, n (\%) } \\
\text { Myalgia, n (\%) } \\
\text { Weakness, n (\%) } \\
\text { Headache, n (\%) } \\
\text { Abdominal pain, n (\%) } \\
\text { Ageusia, n (\%) }\end{array}$ & $\begin{array}{c}12(5) \\
36(44) \\
31(38) \\
384) \\
2(2) \\
4(5) \\
11(14) \\
19(23) \\
5(6) \\
2(2) \\
0\end{array}$ & $\begin{array}{c}18(37) \\
24(49) \\
26(53) \\
6(12) \\
3(6) \\
3(6) \\
3(6) \\
15(31) \\
1(2) \\
5(10) \\
3(6)\end{array}$ & $\begin{array}{l}30(23) \\
60(46) \\
76(59) \\
9(7) \\
5(4) \\
7(5) \\
14(11) \\
34(26) \\
6(5) \\
7(5) \\
3(4)\end{array}$ & $\begin{array}{c}0.005 \\
0.631 \\
0.368 \\
0.080 \\
0.365 \\
0.243 \\
0.300 \\
0.413 \\
1 \\
0.103 \\
0.290\end{array}$ \\
\hline Intensisive care follow up, $n(\%)$ & 0 & $14(29)$ & $14(11)$ & 0.000 \\
\hline $\begin{array}{l}\text { Treatment regimens } \\
\text { Hidroxiklorikin, n (\%) } \\
\text { Favipiravir, n (\%) }\end{array}$ & $\begin{array}{c}81(100) \\
3(4)\end{array}$ & $\begin{array}{c}49(100) \\
27(55)\end{array}$ & $\begin{array}{c}130(100) \\
30(23)\end{array}$ & 0.001 \\
\hline Secondary infection, $\mathrm{n}(\%)$ & $1(1)$ & $13(27)$ & $14(11)$ & 0.000 \\
\hline Discharge time & $5.3 \pm 3.6$ & $10.6 \pm 6(7.5)$ & $7.35 \pm 5.3$ & 0.000 \\
\hline Mortalty, n (\%) & $0(0)$ & $7(14)$ & $7(5.4)$ & 0.000 \\
\hline $\begin{array}{l}\text { Imaging features } \\
\text { Unilateral, single focus, } \mathrm{n}(\%) \\
\text { Unilateral, multble focus, } \mathrm{n}(\%) \\
\text { Bilateral involvement, } \mathrm{n}(\%) \\
\text { Ground-glassopacities, } \mathrm{n}(\%) \\
\text { Consolidation, } \mathrm{n}(\%)\end{array}$ & $\begin{array}{c}16(20) \\
5(6) \\
57(20) \\
73(90) \\
24(30)\end{array}$ & $\begin{array}{c}1(2) \\
2(4) \\
46(94) \\
48(98) \\
17(35)\end{array}$ & $\begin{array}{c}17(13) \\
7(5) \\
103(79) \\
121(93) \\
41(32)\end{array}$ & $\begin{array}{l}0.152 \\
0.564\end{array}$ \\
\hline $\begin{array}{l}\text { Laboratory findings } \\
\text { Hemoglobin, g/dl } \\
\text { WBC, u/L } \\
\text { Neutrophils, u/L } \\
\text { Lymphocytes, u/L } \\
\text { Platelets, u/L } \\
\text { CRP, mg/dl } \\
\mathrm{Na}, \mathrm{mmol} / \mathrm{L} \\
\mathrm{K}, \mathrm{mmol} / \mathrm{L} \\
\text { Ca, mg/dl } \\
\text { Albumin, g/dl,f }\end{array}$ & $\begin{array}{c}12.9 \pm 1.5(13) \\
7206 \pm 6477 \\
4518 \pm 3735 \\
1490 \pm 837 \\
211444 \pm 70364 \\
25.5 \pm 31.3 \\
137.1 \pm 3 \\
4.1 \pm 0.4 \\
4.8 \pm 0.6 \\
3.7 \pm 0.5\end{array}$ & $\begin{array}{c}13 \pm 1.9(13.6) \\
7744 \pm 3468 \\
5294 \pm 3322 \\
1110 \pm 475 \\
194040 \pm 56213 \\
53.7 \pm 57.7 \\
136.1 \pm 3.5 \\
4.1 \pm 0.5 \\
8.6 \pm 0.5 \\
3.5 \pm 0.5\end{array}$ & $\begin{array}{c}12.9 \pm 1.6(13) \\
7220 \pm 5522 \\
4810 \pm 3591 \\
1346 \pm 743 \\
204884 \pm 65711 \\
36.2 \pm 45.1 \\
136 \pm 2.5 \\
4.1 \pm 0.4 \\
8.7 \pm 0.6 \\
3.7 \pm 0.5\end{array}$ & $\begin{array}{l}0.834 \\
0.969 \\
0.234 \\
0.004 \\
0.144 \\
0.002 \\
0.081 \\
0.930 \\
0.022 \\
0.094\end{array}$ \\
\hline
\end{tabular}

CHF: Congestive heart failure, CVH: Coronary vascular diseases, COLD:Chronic obstructive lung disease, DM: Diabetes Mellitus, CKD: Choronic kidney disease, WBC: White blood cell CRP: C- reactive protein, Na: Sodium, K: Potassium, Ca: Calcium, $\rho: 100$ patient. Data are given as (mean+SD) (median) 
load during the pandemic process. Another point is that the rRT-PCR test for SARS-CoV-2 was not positive in all study patients. However, all patients with negative rRT-PCR tests had typical lesions suggestive of COVID-19 disease on their CT. We evaluated a limited number of electrolyte effects on disease prognosis. We did not evaluate the etiology of electrolyte abnormalities due to the high patient load. Only hospitalized persons were included in the study. Therefore, the data are not representative of all COVID-19 patients.

As a result, low $\mathrm{Na}$ and low $\mathrm{Ca}$ levels in COVID-19 patients may be indicative of poor prognosis and long duration of hospitalization. Therefore, it has been concluded that the evaluation of the patients' electrolytes may be useful in the followup of COVID-19.

\section{ACKNOWLEDGEMENT}

Ethical Declaration:Kartal Dr. Lütfi Kırdar City Hospital Clinical Research Ethics Committee approved. (Decision number: 2020/514/180/4)

Conflict of Interest: The authors have no conflicts of interest to declare.

Financial Support: The authors have no affiliation with any organization with a direct or indirect financial interest in the subject matter discussed in the manuscript.

\section{REFERENCES}

1. Guan W, Ni Z, Hu Y et al. Clinical Characteristics of Coronavirus Disease 2019 in China. N Engl J Med. 282020 Apr 30;382(18):1708-1720. doi: 10.1056

2. Pei G, Zhang Z, Peng J, Liu L, Zhang C, Yu C, et al. Renal Involvement and Early Prognosis in Patients with COVID-19 Pneumonia. Journal of the American Society of Nephrology : JASN. 2020.

3. Lippi G, South AM, Henry BM. Electrolyte imbalances in patients with severe coronavirus disease 2019 (COVID-19). Annals of clinical biochemistry. 2020:4563220922255.

4. Guidance to Covid-19 (SARS Cov2 infection), Turkish Health Ministry (2020)[cited 18.05.2020]. Available from: https:// hsgm.saglik.gov.tr/tr/covid-19-i-ngilizce-dokumanlar.html Google Scholar

5. Huang C, Wang Y, Li X et al. Clinicalfeatures of patientsinfectedwith 2019 novelcoronavirus in Wuhan, China. Lancet 2020;395:497-506. doi: 10.1016/S0140- 6736(20)30183-5.

6. Tezcan M.E., Gokce GD, Sen N et al. Baseline electrolyte abnormalities would be related to poor prognosis in hospitalized coronavirus disease 2019 patients New Microbes New Infect. 2020 Sep; 37: 100753. doi: 10.1016/j.nmni.2020.100753

7. Roncon L, Zuin M. Diabetic patients with COVID-19 infection are at higher risk of ICU admission and poor short-term outcome. J Clin Virol. 2020 Jun; 127: 104354. doi: 10.1016/j.jcv.2020.104354

8. Guan WJ, Liang WH, Zhao Y et all. Comorbidity and Its Impact on 1590 Patients With COVID-19 in China: A Nationwide Analysis. Eur Respir J. 2020 May 14;55(5):2000547. doi: 10.1183/13993003.00547-2020

9. Yan Y. Yang Y, Wang F et all. Clinical Characteristics and Outcomes of Patients With Severe COVID-19 With Diabetes. BMJ Open Diabetes Res Care. 2020 Apr;8(1):e001343. doi: 10.1136/bmjdrc-2020-001343.

10. Zoppini G, Fedeli U, Schievano E, Dauriz M, Targher G, Bonora E, Corti MC (2018) Mortality from infectious diseases in diabetes. Nutr Metab Cardiovasc Dis 28:444-450

11. Geerlings SE, Hoepelman AI. Immune dysfunction in patients with diabetes mellitus (DM). FEMS Immunol Med Microbiol 1999; 26: 259-265.

12. Zhou F, Yu T, Du R, et al. Clinical course and risk factors for mortality of adult in patients with COVID-19 in Wuhan, China: a retrospective cohort study. Lancet 2020; 395(10229):1054-62. doi: 10.1016/S0140-6736(20)30566-3.

13. G P Fadini , M L Morieri, E Longato, A Avogaro. Prevalence and Impact of Diabetes Among People Infected With SARSCoV-2. J Endocrinol Invest. 2020 Jun;43(6):867-869.doi: 10.1007/s40618-020-01236-2.

14. Zhou F, Yu T, Du R, et al. Clinical course and risk factors for mortality of adult in patients with COVID-19 in Wuhan, China: a retrospective cohort study. Lancet 2020; 395(10229):1054-62. doi: 10.1016/S0140-6736(20)30566-3.

15. Huang I, Lim MA, Pranata R. Diabetes mellitus is associated with increased mortality and severity of disease in COVID-19 pneumonia - A systematic review, meta-analysis, and meta-regression. Diabetes Metab Syndr. Jul-Aug 2020;14(4):395403. doi: 10.1016/j.dsx.2020.04.018. 
16. Long $\mathrm{C}, \mathrm{Xu} \mathrm{H}$, Shen $\mathrm{Q}$ et al.Diagnosis of the Coronavirus disease (COVID-19): rRT-PCR or CT? Eur J Radiol. 2020 May;126:108961. doi: 10.1016/j.ejrad.2020.108961.

17. Y, Yang Z, Ai T, Wu S, Xia L.Association of "initial CT" findings with mortality in older patients with coronavirus disease 2019 (COVID-19) . Eur Radiol. 2020 Jun 10;1-8. doi: 10.1007/s00330-020-06969-5

18. Alberici F, Delbarba E, Manenti $C$ et al.Management Of Patients On Dialysis And With Kidney Transplant During SARSCOV-2 (COVID-19) Pandemic In Brescia, Italy.Kidney Int Rep.020 Apr 4;5(5):580-585. doi: 10.1016/j.ekir.2020.04.001.

19. Singh $A K$, Gillies $C L$, Singh $R$. Prevalence of co-morbidities and their association with mortality in patients with COVID-19: A systematic review and meta-analysis. Diabetes Obes Metab. 2020 Jun 23;10.1111/dom.14124. doi: 10.1111/dom.14124.

20. Duan J., Wang X., Chi J., Chen H., Bai L., Hu Q. Correlation between the variables collected at admission and progression to severe cases during hospitalization among COVID-19 patients in Chongqing. J Med Virol. 2020.

21. Chawla A., Sterns R.H., Nigwekar S.U., Cappuccio J.D. Mortality and serum sodium: do patients die from or with hyponatremia? Clin J Am Soc Nephrol. 2011;6:960-965.

22. Berni A., Malandrino D., Parenti G., Maggi M., Poggesi L., Peri A. Hyponatremia, IL-6, and SARS-CoV-2 (COVID-19) infection: may all fit together? J Endocrinol Invest. 2020

23. Abbas AK, Fausto N, KumarV. Robbins \& Cotran Pathologic Basis ofDisease, (Robbins Pathology). ISBN:9780808924500;2017

24. Varga Z., Flammer A.J., Steiger P., Haberecker M., Andermatt R., Zinkernagel A.S. Endothelial cell infection and endotheliitis in COVID-19. Lancet. 2020;395(10234):1417-1418.

25. Su H., Yang M., Wan C., Yi L.X., Tang F., Zhu H.Y. Renal histopathological analysis of 26 postmortem findings of patients with COVID-19 in China. Kidney Int. 2020 Jul;98(1):219-227. doi: 10.1016/j.kint.2020.04.003.

26. Yousaf Z., Al-Shokri S.D., Al-Soub H., Mohamed M.F.H. COVID-19-associated SIADH: a clue in the times of pandemic! Am J Physiol Endocrinol Metabol. 2020;318:E882-E885. 